\title{
Article
}

\section{Identifying Strategic Factors of the Implantation CSR in the Airline Industry: The Case of Asia-Pacific Airlines}

\section{Dong-Shang Chang ${ }^{1}$, Sheng-Hung Chen ${ }^{1}$, Chia-Wei Hsu ${ }^{1,2, *}$ and Allen H. Hu ${ }^{3}$}

1 Department of Business Administration, National Central University, Taoyuan City 32001, Taiwan; E-Mails: changds@mgt.ncu.edu.tw (D.-S.C.); m95124003@gmail.com (S.-H.C.)

2 Department of Travel and Eco-tourism, Tungnan University, New Taipei City 222, Taiwan

3 Institute of Environmental Engineering and Management, National Taipei University of Technology, Taipei 10608, Taiwan; E-Mail: allenhu@ mail.ntut.edu.tw

* Author to whom correspondence should be addressed; E-Mail: jcwhsu@ mail.tnu.edu.tw or 103481017@cc.ncu.edu.tw; Tel.: +886-2-8662-5958 (ext. 734); Fax: +886-2-8662-5957.

Academic Editors: Marc A. Rosen and Giuseppe Ioppolo

Received: 1 March 2015 / Accepted: 11 June 2015 / Published: 17 June 2015

\begin{abstract}
Sustainable development has always been the objective of many fields, including the tourism and transportation sector. However, a major part of this sector, the airline industry, deals with many negative impacts, such as air pollution, noise, $\mathrm{CO}_{2}$ emission, and labor practice. Corporate social responsibility (CSR) is a strategic business activity that can enhance the sustainability of the airline industry. The results of the Dow Jones Sustainability Indices (DJSI) reveal that airlines of Western countries exhibit a more remarkable CSR performance than Asia-Pacific airlines, suggesting that the CSR programs of Asia-Pacific airlines need improvement. By constructing an evaluation hierarchy and applying the decision-making trial and evaluation laboratory (DEMATEL) method, this study found that the key strategic factors in the airline industry's implementation of CSR include corporate governance, risk and crisis management, brand management, and product responsibility (safety).
\end{abstract}

Keywords: Sustainable Development Airline industry; DEMATEL; Corporate Social Responsibility 


\section{Introduction}

The airline industry is a part of the service sector that plays an important role in the tourism and transportation industry. At present, the airline industry is operating in a competitive environment [1], with corporate social responsibility (CSR) being the source of competitive advantages [2]. CSR contributes to the long-term value of an airline; this notion is consistent with the Friedmanesque view that airline "executives may consider practicing socially responsible activities... because such practices appear to be accompanied with an increase in their companies' value [over the long-term], which is the ultimate goal of any corporation" [3]. In addition, the effects of CSR on customer loyalty, as well as its identification of areas needing emphasis in terms of organizational involvement and support, has also improved [4]. Cowper-Smith and Grosbois [5] stated that the airline industry has received considerable attention from both the public and academia in regards to CSR issues because of the industry's role in tourism development and its significant environmental and social impacts. As such, CSR has become a critical strategy of airlines, regardless of positive or negative cause.

The CSR of different industries has received a great deal of attention in recent years. As such, CSR rating indices have been developed for evaluating the CSR performance of corporations; one of the most prominent sustainability indices is the Dow Jones Sustainability Indices (DJSI) [6]. Assessment of the 2014 DJSI survey of 16 airlines (62\% of the 26 airlines that were invited to participate) showed that the sampled airlines exhibited a market capitalization of $66 \%$. The average score of the airline industry was lower than that of all of the participating industries [7], indicating that the CSR performance of the airline industry could still be improved. The leading companies in the airline industry are from Western countries. By contrast, the rankings reveal that the airlines in Asia-Pacific countries exhibit poor CSR performance. The possible reason for such finding is that the concept of CSR originated from Western countries, and the Asia-Pacific region is just starting to adopt the practice.

The successful implementation of a comprehensive CSR strategy requires many resources and changes of organization, whether cross-functional collaboration or basic thinking on daily work. Therefore, the main purpose of this research is to construct an evaluating model for airlines in Asia-Pacific that can examine the importance and interrelationship of each CSR issue. The evaluation hierarchy developed in this research not only includes basic CSR issues but also covers the specific issues of the airline industry in Asia-Pacific. To ensure comprehensiveness and suitability to airlines, the proposed evaluation hierarchy was based on the main criteria of the DJSI assessment and the mapping of the most representative guidelines or critical regulations of CSR issues in the airline industry, such as Global Reporting Initiative (GRI) G3.1 [8], GRI G4 [9], International Air Transport Association (IATA) [10], and International Civil Aviation Organization (ICAO) [11].

Numerous criteria and dimensions related to the CSR of the airline industry should be considered at the same time. This research applied the Decision-Making Trial and Evaluation Laboratory (DEMATEL) method to deal with causal relationships among the evaluation criteria in the CSR strategy of the airline industry. The DEMATEL method has been successfully applied in many situations, such as airline green supply chain selection, risk assessment, and CSR problems [12-19]. The result of the DEMATEL method is a visual map that includes the relation of the criteria and the relative importance within the evaluation hierarchy. The results of this study can help the airline industry identify the key CSR issues for efficient resource allocation in the planning of CSR strategies. 
The remainder of this paper is organized as follows. Section 2 introduces the definition of CSR and previous studies on CSR in the airline industry. Section 3 discusses the CSR issues of the airline industry and introduces the characteristic evaluation criteria. Section 4 presents a brief introduction of the DEMATEL method and proposes the establishment of a model for the DEMETAL method. Section 5 provides the results of the analysis. Section 6 presents the conclusions drawn in this paper and suggests future research directions.

\section{Literature Review}

\subsection{Definition of Corporate Social Responsibility (CSR)}

In the past decade, CSR has been the primary subject of a limited number of studies from a small academic community of practice and these studies have primarily focused on three macrolevel topic areas: implementation; the economic rationale for acting more responsibly; and the social relations of CSR [20]. Both academics and practitioners have explored concepts similar to CSR, such as corporate social performance (CSP), corporate sustainability (CS), and environmental management (EM) [21]. Nonetheless, this paper is not concerned with providing precise definitions. According to Elkington [22], the definition of CSR can be broken down into three main aspects: equity-social concerns, ecological-environmental considerations, and economic mergers. The World Business Council on Sustainable Development (WBCSD) has proposed a more extensive definition of CSR: "Corporate social responsibility is the continuing commitment by business to contribute to economic development while improving the quality of life of the workforce and their families as well as of the community and society at large" [23]. Although CSR has different definitions, the basic idea of CSR is to examine how businesses integrate stakeholder interests with social values in order to consolidate the relation between organization and society [24].

\subsection{CSR in the Airline Industry}

Although many studies have explored the airline industry, few have focused on this industry's CSR activities. Coles et al. [20] presented a review of tourism and CSR that compared recent academic research on CSR in the tourism sector. The research indicated that in the tourism sector, the airline industry attracts the most academic attention. The reasons for this include the industry's contributions to climate change and the fact that airlines have several characteristics similar to those of manufacturing industries: intense regulation, high entry barriers, high capital costs, and tendencies toward oligopolies [25]. At present, studies on the CSR of the airline industry is more focused on cost assessment [18], benefits quantitative assessment [3,26,27], CSR motivations [25] and CSR reporting [28,29], but less on CSR strategic factors.

\section{CSR Issues of the Airline Industry}

The airline industry plays an important role in the tourism sector, thus encouraging the airline industry to live up to the high expectations in regards to CSR practices. The airline industry induces not only environmental effects but also economic and social effects. As Coles et al. [20] pointed out, the airline industry is more concerned with environmental issues than its economic or social implications [3]. 
By analyzing the relationship of sustainability scores and financial performance of 311 firms, Chang and Kou [30] showed that improved sustainability tends to positively influence firm profitability. Coles et al. [20] reviewed the relationship between tourism and CSR, and they mentioned that CSR performance can enhance the profitability and value of firms. Lee and Park [3] also investigated the same relationship for airline companies.

An average airline company publishes CSR sustainability reports or sustainable development reports to reflect on its economic, environmental, and social contributions along with the numerous sustainable issues. Hsu [14] stated that the key concept of a CSR report is stakeholder engagement. A sustainability report presents the progress of managerial efforts to enhance the company in society and to communicate their achievements to stakeholders. However several guidelines are observed in preparing sustainable reports, including GRI G3.1, GRI G4, ISO 26000, and SA 8000, which also provide enterprises with a basic framework when working on sustainable reports. These guidelines provide a clearer examination of sustainable development; however, these guidelines are applicable to all industries. Therefore, some specific issues related to the airline industry are not included.

The airline industry-specific CSR issues are evaluated with sustainable evaluation indices or CSR rating systems. Such systems include the DJSI, FTSE KLD 400 Social Index, and FTSE4GOOD Global Index [24]. The most prominent sustainability index is the DJSI, as shown in a survey of more than 1000 sustainability professionals as a part of the Rate the Raters project, which found that the DJSI showed the highest credibility of 16 well-established ratings [6]. The individual questionnaire of the DJSI may be used for many different industry groups; however, the airline industry deals with specific issues, including fleet management, efficiency, reliability, biofuel, and noise [7].

The IATA is the global trade association for airlines. It represents 240 airlines, or $84 \%$ of the total air traffic. IATA is an organization that supports many areas of aviation activity and helps formulate industry policy on critical aviation issues [10]. IATA has enumerated several issues related to sustainable aviation, including safety, climate change, aircraft noise, and local air quality.

The other major organization of the aviation industry is the ICAO, which is a UN specialized agency. It works with the convention's 191 signatory states, as well as with global industry and aviation organizations to develop international standards and recommended practices (SARPs), which were used by the United States during the development of their legally binding national civil aviation regulations. The ICAO 2013 environmental report also mentioned aircraft noise, local air quality, and global emissions. The present study collected the CSR issues of the airline industry for DJSI, GRI G4, IATA, and ICAO, as shown in Figure 1. 


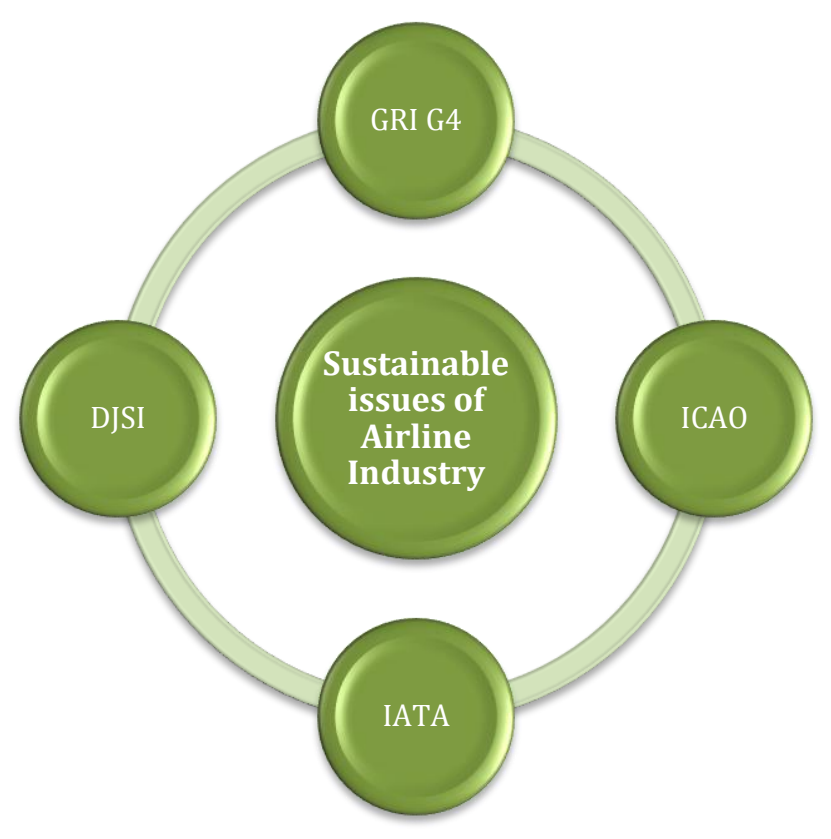

Figure 1. CSR issues of airline industry.

This research collated the key airline CSR issues. In addition, this research used the DJSI airline industry criteria as the basis for mapping the GRI guidelines [8,9], ITAT [10] and ICAO [31] requirements, and mapping the Carbon Disclosure Project (CDP) [32], United Nations Global Compact (UNGC) [33], and International Labor Organization's (ILO) initiatives [34] or regulations that are related to CSR. These initiatives helped in the construction of the evaluation hierarchy of airline CSR issues. A total of 22 evaluation criteria were built on the basis of the DJSI's airlines sector evaluating criteria and the integration of GRI G3.1, GRI G4.0, CDP, UN GC, IATA and ICAO's requirements, as shown in Table 1. 
Table 1. Evaluation Hierarchy of Airline Industry CSR Issues.

\begin{tabular}{|c|c|c|c|c|}
\hline Dimension & & Criteria & Definition & Source \\
\hline \multirow{10}{*}{$\begin{array}{l}\text { Economic } \\
\text { Dimension }\end{array}$} & $\mathrm{EC} 1$ & Corporate Governance & $\begin{array}{c}\text { Board structure, responsibilities and committees, corporate governance policy, } \\
\text { board diversity, board effectiveness, audit conflict of interest, and } \\
\text { transparency of senior management remuneration }\end{array}$ & $\begin{array}{l}\text { Dow Jones Sustainability } \\
\text { Indices (DJSI), Global } \\
\text { Reporting Initiative (GRI) }\end{array}$ \\
\hline & $\mathrm{EC} 2$ & $\begin{array}{l}\text { Risk and Crisis } \\
\text { Management }\end{array}$ & $\begin{array}{l}\text { Analysis of risks, risk correlation, sensitivity analysis and stress testing, } \\
\text { risk response strategy, and crisis preparedness }\end{array}$ & DJSI, GRI \\
\hline & EC3 & $\begin{array}{l}\text { Codes of Conduct/ } \\
\text { Compliance/Corruption } \\
\text { and Bribery } \\
\end{array}$ & $\begin{array}{l}\text { Focus issues, scope of policy, systems/procedures, business relationships, } \\
\text { and reporting on breaches }\end{array}$ & DJSI, GRI G4 (Society) \\
\hline & EC4 & Antitrust Policy & Antitrust policy, coverage of antitrust policy, antitrust compliance, and reporting process etc. & DJSI, GRI G4 (Society) \\
\hline & EC5 & $\begin{array}{l}\text { Customer Relationship } \\
\text { Management }\end{array}$ & $\begin{array}{l}\text { Satisfaction measurement, customer feedback process, availability of data to the customer } \\
\text { center, analysis of customer value, and complaints management }\end{array}$ & DJSI \\
\hline & EC6 & Brand Management & $\begin{array}{c}\text { Brand-related expenses, branding strategies, brand metrics used, } \\
\text { and stakeholder perception analysis }\end{array}$ & $\begin{array}{c}\text { DJSI, GRI G4 } \\
\text { (Market Presence) }\end{array}$ \\
\hline & EC7 & $\begin{array}{l}\text { Supply Chain } \\
\text { Management }\end{array}$ & $\begin{array}{l}\text { Awareness, risk analysis, risk management measures, } \\
\text { supply chain management strategy, and transparency }\end{array}$ & $\begin{array}{c}\text { DJSI, GRI G4 } \\
\text { (Procurement Practices) }\end{array}$ \\
\hline & EC8 & Efficiency * & Passenger load factor and share of short-haul flights & DJSI \\
\hline & EC9 & Fleet Management * & Fleet age, measures for improving fuel efficiency & DJSI \\
\hline & $\mathrm{EC} 10$ & Reliability * & Arrival delay indicators and management approach & DJSI \\
\hline
\end{tabular}


Table 1. Cont.

\begin{tabular}{|c|c|c|c|c|}
\hline Dimension & & Criteria & Definition & Source \\
\hline \multirow{5}{*}{$\begin{array}{l}\text { Environmental } \\
\text { Dimension }\end{array}$} & EN1 & Climate Change & $\begin{array}{c}\text { Direct GHG emissions, indirect GHG emissions, } \\
\text { and energy consumption }\end{array}$ & $\begin{array}{c}\text { DJSI, Carbon Disclosure Project (CDP), GRI, } \\
\text { International Civil Aviation Organization } \\
\text { (ICAO), International Air Transport } \\
\text { Association (IATA) }\end{array}$ \\
\hline & EN2 & Biofuel */Alternative Energy & $\begin{array}{c}\text { Biofuel usage volume, research program participation, } \\
\text { and ground alternative energy usage }\end{array}$ & DJSI, CDP, GRI, ICAO, IATA \\
\hline & EN3 & Noise * & $\begin{array}{l}\text { Noise management approach and reduction of project and } \\
\text { investment }\end{array}$ & ICAO, IATA \\
\hline & EN4 & $\begin{array}{l}\text { Environmental Policy/Management } \\
\text { System }\end{array}$ & $\begin{array}{l}\text { Coverage of corporate requirements/guidelines, centralized data } \\
\text { collection system, environmental management system (EMS) is } \\
\text { verified/audited/certified }\end{array}$ & DJSI, UN GC, GRI G3.1; G4 \\
\hline & EN5 & $\begin{array}{c}\text { Operational } \\
\text { Eco-Efficiency }\end{array}$ & $\begin{array}{l}\text { Water usage, waste generation, } \\
\text { NOx emissions, and SOx emissions }\end{array}$ & DJSI, CDP, GRI, ICAO, IATA \\
\hline \multirow{7}{*}{$\begin{array}{c}\text { Social } \\
\text { Dimension }\end{array}$} & $\mathrm{SO} 1$ & $\begin{array}{l}\text { Environment and Social Reporting } \\
\text { (Information Disclosure) }\end{array}$ & $\begin{array}{l}\text { Quality of social and environment reporting, materiality, } \\
\text { coverage, assurance, and quantitative data }\end{array}$ & DJSI \\
\hline & $\mathrm{SO} 2$ & $\begin{array}{l}\text { Labor Practice Indicators and Human } \\
\text { Rights }\end{array}$ & $\begin{array}{l}\text { ILO- and UNGC-related indicators, } \\
\text { human rights, labor practices, and decent work }\end{array}$ & $\begin{array}{c}\text { DJSI, GRI G4 (Human Rights, Labor } \\
\text { Practices, and Decent Work), ILO, UNGC }\end{array}$ \\
\hline & $\mathrm{SO} 3$ & Human Capital Development & $\begin{array}{l}\text { Skill mapping and developing process, human capital } \\
\text { performance, and learning and development process }\end{array}$ & $\begin{array}{l}\text { DJSI, GRI G4 (Labor Practices } \\
\text { and Decent Work) }\end{array}$ \\
\hline & $\mathrm{SO} 4$ & Talent Attraction and Retention & $\begin{array}{l}\text { Salary structure, employee turnover rate, } \\
\text { and employee satisfaction }\end{array}$ & $\begin{array}{c}\text { DJSI, GRI G4 (Labor } \\
\text { Practices and Decent Work) }\end{array}$ \\
\hline & $\mathrm{SO} 5$ & Corporate Citizenship and Philanthropy & $\begin{array}{l}\text { Group-wide strategy, performance } \\
\text { management process, and KPI }\end{array}$ & DJSI, GRI G4 (Society ) \\
\hline & SO6 & Stakeholder Engagement & $\begin{array}{l}\text { Stakeholder engagement approach, materiality analysis process, } \\
\text { and feedback approach }\end{array}$ & DJSI, GRI \\
\hline & $\mathrm{SO} 7$ & Product Responsibility (Safety) & $\begin{array}{c}\text { Safety management approach, training system, management } \\
\text { process, and audit and safety performance }\end{array}$ & GRI, ICAO, IATA \\
\hline
\end{tabular}

Note:* is the airline specific criteria. 


\section{Research Method}

DEMATEL is a comprehensive method for building and analyzing a structural model involving causal relationships between complex factors [35]. Developed by the Science and Human Affairs Program of the Battelle Memorial Institute in Geneva between 1972 and 1976, it has been used for studying and solving the complicated and intertwined group of problems. DEMATEL was developed in the belief that pioneering and appropriate use of scientific research methods could improve understanding of the specific problematique (the cluster of intertwined problems) and contribute to the identification of workable solutions by a hierarchical structure. The methodology, according to the concrete characteristics of objective affairs, can confirm the interdependence among the variables/attributes and restrict the relationship that reflects the characteristic with an essential system and development trend [36-39]. The end product of the DEMATEL process is a visual representation — an individual map of the mind - by which the respondent organizes his or her own action in the world.

The steps of the DEMATEL method are shown in Figure 2. First, the evaluation hierarchy is constructed. Then, an expert team is selected to apply the expert questionnaire. Then, the DEMATEL method is used to calculate (the detailed calculation steps of the DEMATEL method are summarized below) the matrix of total relation. Finally, $r$ and $c$ are calculated for the degree of influence, and $r+c$ and $r-c$ are calculated to draw the influence map of the total relationship.

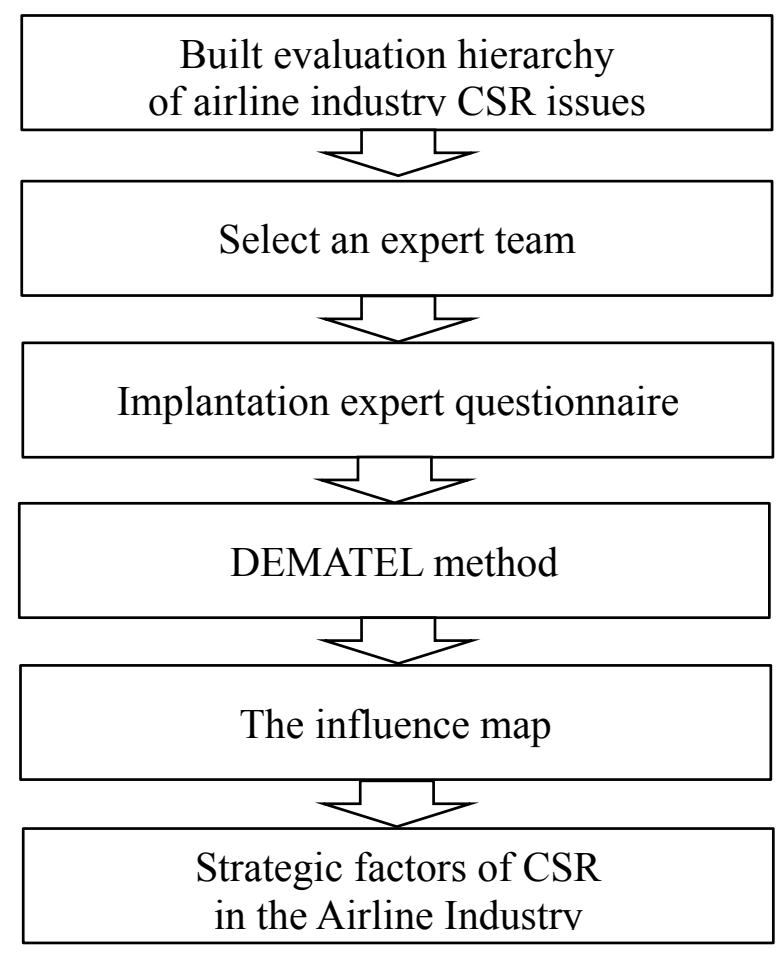

Figure 2. DEMATEL method apply process.

According to Tsai and Hsu [18], Hsu et al. [38] and Tzeng et al. [40], the DEMATEL method can be summarized in the following steps.

Step 1: Find the average matrix. Assuming $\mathrm{H}$ experts are surveyed in this study and $\mathrm{n}$ factors are to be considered, each stakeholder is asked to indicate the degree to which he or she believes a factor $i$ affects factor $j$. These pairwise comparisons between any two factors are denoted by aij and are given 
an integer score of $0,1,2,3$, and 4, representing "no influence," "low influence," "medium influence," "high influence," and "very high influence," respectively. The scores by each expert yield a $n \times n$ nonnegative answer matrix $X^{k}=\left[x_{i j}^{k}\right]$, with $1 \leq k \leq H$. Thus, $X^{1}, X^{2}, \ldots, X^{H}$ are the answer matrices for each of the $H$ experts, and each element of $X^{k}$ is an integer denoted by $x_{i j}^{k}$. The diagonal elements of each answer matrix $X^{k}$ are all set to 0 . The $n \times n$ average matrix $\boldsymbol{A}$ for all expert opinions can be computed by averaging the scores of $H$ experts as follows:

$$
a_{i j}=\frac{1}{H} \sum_{k=1}^{H} x_{i j}^{k}
$$

The average matrix $\mathrm{A}=\left[\alpha_{i j}\right]$ is also called the initial direct relation matrix. A shows the initial direct effects that a factor exerts on and receives from other factors. In addition, the causal effect between each pair of factors can be mapped out in a system by drawing an influence map. Figure 3 below is an example of such an influence map. Here, each letter represents a factor in the system. An arrow from $c$ to $d$ shows the effect that $\mathrm{c}$ has on $\mathrm{d}$, and the strength of its effect is 4 . DEMATEL can convert the structural relations among the factors of a system into an intelligible map of the system.

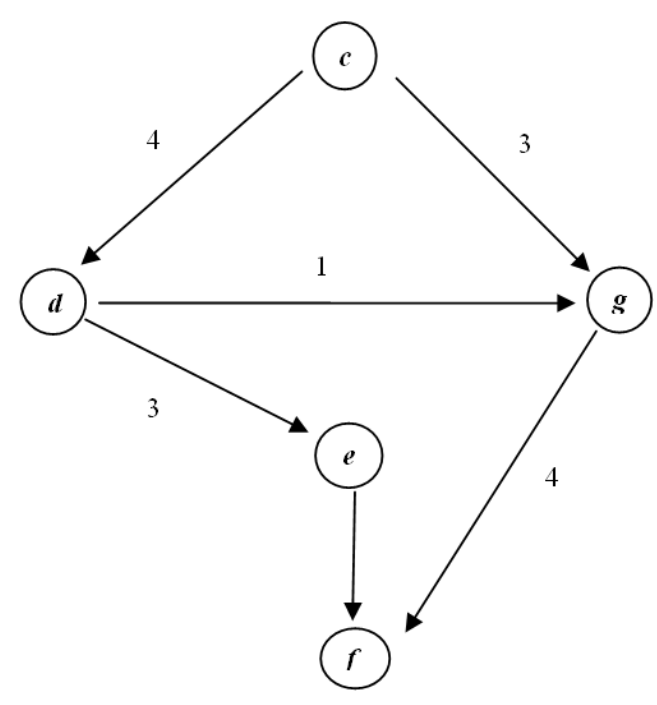

Figure 3. Example of an influence map.

Step 2: Calculate the normalized initial direct-relation matrix. The normalized initial direct-relation matrix $\boldsymbol{D}$ is obtained by normalizing the average matrix $\boldsymbol{A}$ in the following way:

$$
\text { Let } s=\max \left(\max _{1 \leq i \leq n} \sum_{j=1}^{n} a_{i j}, \max _{1 \leq j \leq n} \sum_{i=1}^{n} a_{i j}\right)
$$

Then

$$
D=\frac{A}{S}
$$

Given that the sum of each row $j$ of matrix $\boldsymbol{A}$ represents the total direct effects that factor $i$ on the other factors, $\max _{1 \leq i \leq n} \sum_{j=1}^{n} a_{i j}$ represents the total direct effects of the factor with the most direct effects on 
others. Similarly, considering that the sum of each column $i$ of matrix $\boldsymbol{A}$ represents the total direct effects received by factor $i, \max _{1 \leq j \leq n} \sum_{i=1}^{n} a_{i j}$ represents the total direct effects received of the factor that receives the most direct effects from others. The positive scalar $s$ takes the lesser of the two values as the upper limit, and the matrix $\boldsymbol{D}$ is obtained by dividing each element of $\boldsymbol{A}$ by the scalar $s$. Each element $d_{i j}$ of matrix $\boldsymbol{D}$ has a value of 0 or less than 1.

Step 3: Compute the total relation matrix. A continuous decrease of the indirect effects of problems along the powers of matrix $\boldsymbol{D}$, e.g., $\boldsymbol{D}^{2}, \boldsymbol{D}^{3}, \ldots, \boldsymbol{D}^{\infty}$, guarantees convergent solutions to the matrix inversion similar to an absorbing Markov chain matrix. $\lim _{m \rightarrow \infty} \boldsymbol{D}^{m}=[0]_{n \times n}$ and $\lim _{m \rightarrow \infty}\left(\boldsymbol{I}+\boldsymbol{D}+\boldsymbol{D}^{2}+\boldsymbol{D}^{3}+\ldots+\boldsymbol{D}^{m}\right)=(\boldsymbol{I}-\boldsymbol{D})^{-1}$, where 0 is the $n \times n$ null matrix and $I$ is the $n \times n$ identity matrix. The total relation matrix $\boldsymbol{T}$ is an $n \times n$ matrix and is defined as follows:

$$
\boldsymbol{T}=\left[t_{i j}\right] i, j=1,2, \ldots, n
$$

where

$$
\begin{gathered}
\boldsymbol{T}=\boldsymbol{D}+\boldsymbol{D}^{2}+\ldots+\boldsymbol{D}^{m}=\boldsymbol{D}+\boldsymbol{D}^{2}+\ldots+\boldsymbol{D}^{\mathrm{m}}=\boldsymbol{D}\left(I+\boldsymbol{D}+\boldsymbol{D}^{2}+\ldots+\boldsymbol{D}^{m-1}\right) \\
=\boldsymbol{D}\left[\left(I+\boldsymbol{D}+\boldsymbol{D}^{2}+\ldots+\boldsymbol{D}^{m-1}\right)(1-\boldsymbol{D})\right](1-\boldsymbol{D})^{-1}=\boldsymbol{D}(\boldsymbol{I}-\boldsymbol{D})^{-1}, \text { as } m \rightarrow \infty
\end{gathered}
$$

In addition, $\boldsymbol{r}$ and $\boldsymbol{c}$ are defined as $n \times 1$ vectors representing the sum of rows and sum of columns of the total relation matrix $\boldsymbol{T}$ as follows:

$$
\begin{aligned}
& \boldsymbol{r}=\left[r_{i}\right]_{n \times 1}=\left(\sum_{j=1}^{n} t_{i j}\right)_{n \times 1} \\
& \boldsymbol{c}=\left[c_{j}\right]_{1 \times n}^{\prime}=\left(\sum_{i=1}^{n} t_{i j}\right)_{1 \times n}^{\prime}
\end{aligned}
$$

where superscript ' denotes to transpose.

When $r_{i}$ is the sum of the $i$ th row in matrix $\boldsymbol{T}$, then $r_{i}$ shows the total effects, both direct and indirect, given by factor $i$ to the other factors. When $c_{j}$ denotes the sum of the $j$ th column in matrix $\boldsymbol{T}$, then $c_{j}$ shows the total effects, both direct and indirect, received by factor $j$ from the other factors. Thus, when $j=i$, the sum $\left(r_{i}+c_{i}\right)$ yields an index that represents the total effects both given and received by factor $i$. In other words, $\left(r_{i}+c_{i}\right)$ shows the degree of importance (total sum of effects given and received) that factor $i$ plays in the system. In addition, the difference $\left(r_{i}-c_{i}\right)$ shows the net effect that factor $i$ contributes to the system. When $\left(r_{i}-c_{i}\right)$ is positive, factor $i$ is a net causer, and when $\left(r_{i}-c_{i}\right)$ is negative, factor $i$ is a net receiver.

Teng suggested that between 5 and 15 expert questionnaires are needed [41], whereas Saaty and Vargas [42] postulated that 3 to 7 expert questionnaires are suitable, since expert questionnaires are used as an expert's judgment rather than statistical concepts [43]. Tzeng and Huang [44] consulted five experts and emphasized their experience. In the present study, six experts were selected from industrial, official, and academic institutions with professional knowledge and experience. Two experts are CSR managers from global airlines. Two experts are in charge of CSR programs in global airlines. One expert is a representative of the Taiwan Civil Aeronautics Administration. One expert is a scholar from the 
Department of Air Transportation. The backgrounds of the expert team are shown in Table 2. The matrix of total relation is shown in Appendix. The influence of the degree of purchasing concern factors is shown in Table 3, and the causal diagram of total relationship is shown in Figure 4.

Table 2. Expert team backgrounds.

\begin{tabular}{|c|c|c|c|}
\hline Background & Background & Male/Female & Professional Experience \\
\hline Expert \#1 & $\begin{array}{l}\text { Global airlines } \\
\text { CSR manager }\end{array}$ & Male & $\begin{array}{l}\text { Over } 10 \text { years' airline management experience, } \\
\text { responsible for environment division } \\
\text { and corporate safety office }\end{array}$ \\
\hline Expert \#2 & $\begin{array}{l}\text { Global airlines } \\
\text { CSR project manager }\end{array}$ & Female & $\begin{array}{c}10 \text { years' airline experience and now is executive } \\
\text { secretary of airline's CSR committee }\end{array}$ \\
\hline Expert \#3 & $\begin{array}{l}\text { Taiwan civil aeronautics } \\
\text { administration (CAA) }\end{array}$ & Male & $\begin{array}{c}\text { Over } 10 \text { years' CAA experience, now responsible } \\
\text { for environmental management }\end{array}$ \\
\hline Expert \#4 & $\begin{array}{l}\text { Global airlines } \\
\text { CSR manager }\end{array}$ & Male & $\begin{array}{c}\text { Over } 10 \text { years' airline management experience of } \\
\text { environmental division }\end{array}$ \\
\hline Expert \#5 & $\begin{array}{c}\text { Professor of } \\
\text { air transportation } \\
\text { management department }\end{array}$ & Female & $\begin{array}{c}\text { Over } 20 \text { journal article publications in airline } \\
\text { operation and management field }\end{array}$ \\
\hline Expert \#6 & $\begin{array}{l}\text { Global airlines } \\
\text { CSR project manager }\end{array}$ & Female & $\begin{array}{l}3 \text { years' airline experience and over } 5 \text { years' CSR } \\
\text { project management experience. } \\
\text { Responsible for publishing CSR report for airlines. }\end{array}$ \\
\hline
\end{tabular}

\section{Results and Discussion}

First, we obtained the average matrix from six expert questionnaires using Equation (1). We then calculated the normalized initial direct-relation matrix based on average matrix by using Equations (2) and (3). Equation (4) was then used to compute the total relation matrix. The $r$ value and $c$ value of each criterion are then calculated using Equations (5) and (6). We then obtained the values of $r+c$ and $r-c$ of each criterion, which are presented in Table 2. By drawing the values of $r+c$ and $r-c$, we obtained the influence map, which is presented in Figure 4.

According to the results of the DEMATEL method, corporate governance (EC1) is the most critical criterion and the key criterion influencing all other criteria. The importance of corporate governance is manifested not only in CSR activities but also in strategies across enterprises. Corporate governance is the most critical criterion for CSR, and it can be inducted for the following reasons. First, CSR is a new concept in enterprises, and new concepts need support from top management. Second, CSR does not easily yield the apparent performance in the short term [3]. Third, CSR activities need many functions or department integration and coordination. Fourth, CSR is a high-level and long-term strategy for enterprises, and it influences many other strategies. The importance of firm value in governance and its relationships with CSR was also mentioned by Ammann and Schmid [45]. However, they outlined good corporate governance, which seemed to assure that CSR expenditures are profit-oriented rather than serving the personal ambitions of managers.

The second critical criterion is risk and crisis management (EC2). Risk management is a basic concept of CSR. The strong relationship between risk management and CSR has also been proven by Olson and 
$\mathrm{Wu}$ [46] in a book review of Innovative CSR: From Risk Management to Value Creation. They mentioned CSR as a major issue in enterprise risk management from the societal and business perspectives. If an enterprise reduces risks to the lowest and simultaneously allows optimum opportunities, this enterprise will have the most sustainability. However, in the real world, risks and opportunities usually come at the same time. Thus, risk and crisis management is very important. In addition, risk management is the key effect criterion influenced by others. Risk management is influenced by the other 13 criteria, and several criteria did not directly influence risk management, including customer relationship management (EC5), operational eco-efficiency (EN5), labor practice indicators and human rights (SO2), human capital development (SO3), talent attraction and retention (SO4), and corporate citizenship and philanthropy (SO5). However, these criteria also influenced risk management, albeit indirectly. Only biofuel/alternative energy (EN2) and noise (EN3) are independent of the result; the reasons are discussed later in this paper.

Table 3. The degree of influence of airline CSR strategy.

\begin{tabular}{|c|c|c|c|c|c|}
\hline Code & Criteria & $r$ & $c$ & $r+c$ & $r-c$ \\
\hline $\mathrm{EC} 1$ & Corporate Governance & 2.89 & 2.40 & 5.29 & 0.49 \\
\hline $\mathrm{EC} 2$ & Risk and Crisis Management & 2.49 & 2.50 & 4.99 & -0.01 \\
\hline EC3 & $\begin{array}{c}\text { Codes of Conduct/ } \\
\text { Compliance/Corruption and } \\
\text { Bribery }\end{array}$ & 1.96 & 1.66 & 3.62 & 0.30 \\
\hline EC4 & Antitrust Policy & 1.70 & 1.41 & 3.11 & 0.29 \\
\hline EC5 & $\begin{array}{c}\text { Customer Relationship } \\
\text { Management }\end{array}$ & 1.68 & 2.12 & 3.8 & -0.44 \\
\hline EC6 & Brand Management & 2.24 & 2.49 & 4.73 & -0.25 \\
\hline EC7 & Supply Chain Management & 1.80 & 2.09 & 3.89 & -0.29 \\
\hline EC8 & Efficiency & 2.06 & 2.51 & 4.57 & -0.45 \\
\hline EC9 & Fleet Management & 1.92 & 2.16 & 4.08 & -0.24 \\
\hline EC10 & Reliability & 2.11 & 2.29 & 4.4 & -0.18 \\
\hline EN1 & Climate Change & 1.74 & 1.60 & 3.34 & 0.14 \\
\hline EN2 & Biofuel/alternative energy & 1.54 & 1.43 & 2.97 & 0.11 \\
\hline EN3 & Noise & 1.37 & 1.34 & 2.71 & 0.03 \\
\hline EN4 & $\begin{array}{l}\text { Environmental Policy/ } \\
\text { Management System }\end{array}$ & 1.88 & 1.86 & 3.74 & 0.02 \\
\hline EN5 & Operational Eco-Efficiency & 1.55 & 1.84 & 3.39 & -0.29 \\
\hline $\mathrm{SO} 1$ & $\begin{array}{c}\text { Environment and Social Reporting } \\
\text { (Information Disclose) }\end{array}$ & 1.96 & 1.90 & 3.86 & 0.06 \\
\hline $\mathrm{SO} 2$ & $\begin{array}{c}\text { Labor Practice Indicators and } \\
\text { Human Rights }\end{array}$ & 1.75 & 1.53 & 3.28 & 0.22 \\
\hline $\mathrm{SO} 3$ & Human Capital Development & 1.92 & 1.65 & 3.57 & 0.27 \\
\hline $\mathrm{SO} 4$ & Talent Attraction and Retention & 1.94 & 1.77 & 3.71 & 0.17 \\
\hline $\mathrm{SO5}$ & $\begin{array}{c}\text { Corporate Citizenship and } \\
\text { Philanthropy } \\
\end{array}$ & 1.32 & 1.54 & 2.86 & -0.22 \\
\hline SO6 & Stakeholder Engagement & 1.83 & 1.80 & 3.63 & 0.03 \\
\hline SO7 & Product Responsibility (Safety) & 2.24 & 2.00 & 4.24 & 0.24 \\
\hline
\end{tabular}


The third critical criterion is brand management (EC6). Customers are influenced by many factors, such as cost and scheduled flight. However, brand image can be additionally attractive to customers and draw increased pricing power on the market. The fourth critical criterion is product responsibility (safety) (SO7). Safety is the most important concern of airlines and passengers. The IATA and ICAO have also placed many policies and audit focus on safety, such as the IATA operational safety audit (IOSA) program or the ICAO safety management system (SMS).

Biofuel/alternative energy (EN2) and noise (EN3) are independent, and they do not influence nor get influenced by the other criteria. For biofuel, many safety concerns have to be tested and verified. In terms of cost, fuel price is the greatest expense of airlines. Several airlines, such as Air France KLM [47], Lufthansa [48], Qantas [49], ANA [50], and Cathay Pacific [51], have invested in many projects and have joined biofuel alliances, such as the European Advanced Biofuel Flight Path 2020 initiative [52] to protect biofuel resources and reduce biofuel price. Noise influences local residents, and very limited resources can help reduce the noise. Current noise-reduction approaches that are used include electronic technologies, such as such as eTruck, and follow the "Balanced Approach to Aircraft Noise Management," which was reaffirmed by ICAO in 2007 to reduce airport operation noise [53]. These two criteria exhibit similar characteristics.

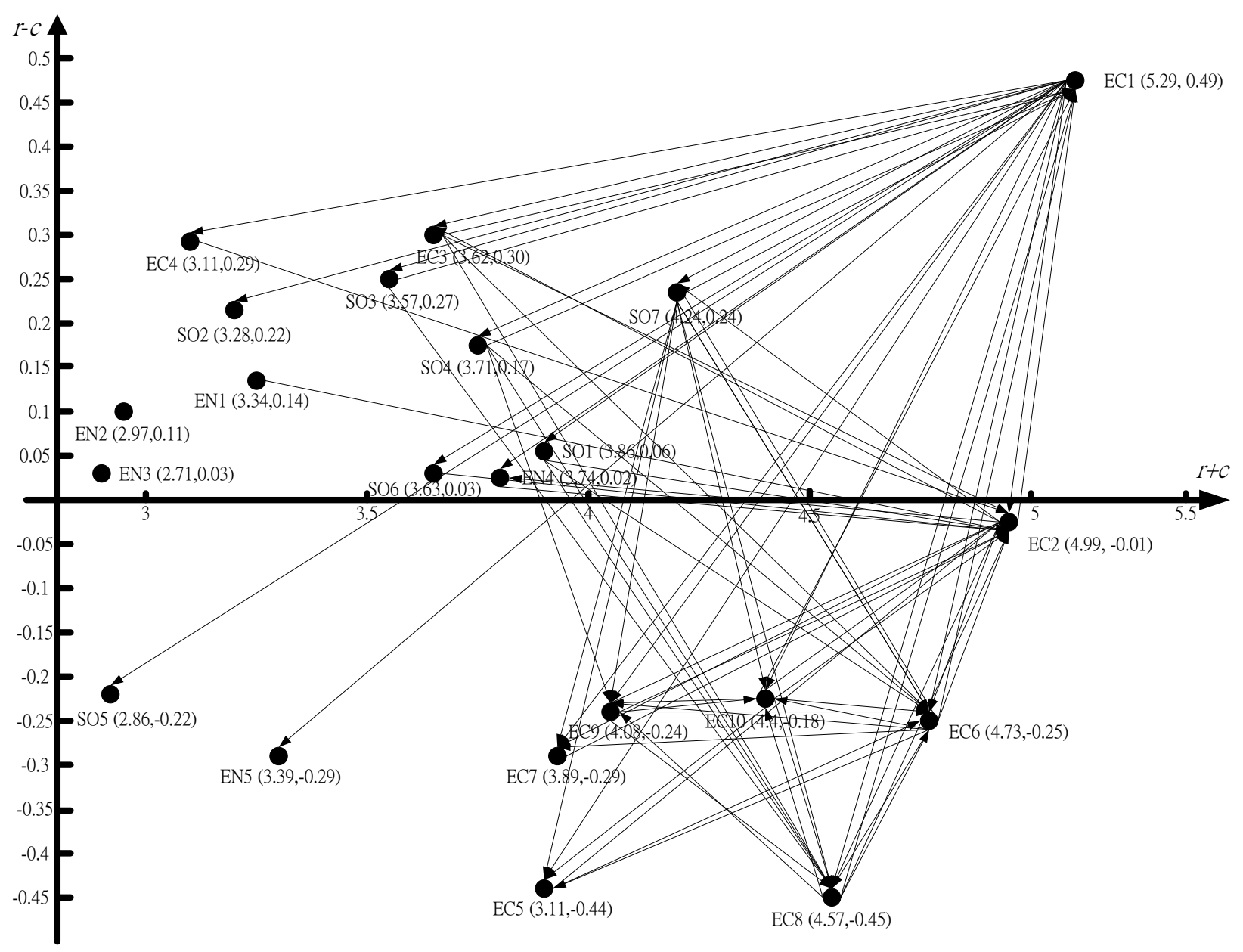

Figure 4. The influence map of total relationship. 
To further verify the results, this research interviewed senior managers of global airlines. Five senior vice presidents and one vice president of Asian global airlines were interviewed for this study to obtain the real viewpoint of frontline managers as to how their CSR strategies affect their respective airlines. The key interview excerpts are shown in Table 3.

On the basis of the interviews, the key factors in CSR strategy are corporate governance, customer relationship management, brand management, efficiency, fleet management, climate change, biofuel/alternative energy, operational eco-efficiency, environment and social reporting (information disclosure), labor practice indicators and human rights, human capital development, talent attraction and retention, corporate citizenship and philanthropy, stakeholder engagement, and product responsibility (safety). The results show that the evolution hierarchy built in this research can cover all key factors of the CSR strategy of the airline industry.

The interview of the senior managers revealed that functional managers are driven by different motivations. However, the evaluation hierarchy built in this research increased the comprehensiveness of these considerations. The DEMATEL method discussed the relationship between each criterion and presented the visible influence map for easily realizing the interrelations of the different criteria. Moreover, comparison of the results proved that CSR strategy entails multiple decision-making processes. DEMATEL is suitable in building and analyzing a structural model involving causal relationships between complex factors.

In recent years, airlines have faced an extremely competitive and challenging environment. Fuel cost and low-cost carriers have forced airlines to rethink their business plans and adapt their long-term growth strategies [7]. The 2013 statistics of IATA show that global passenger market revenue passenger kilometer (RPK) has grown by 5.2\% compared to 2012 figures; however, total supply volume also grew by $4.8 \%$. The freight ton kilometer (FTK) of the ton market grew by $1.4 \%$ in 2013 , but total supply volume (passenger plane belly cargo compartment) grew by $2.6 \%$.

Consolidation continued throughout the industry to deal with this challenging environment, and new route-sharing partnerships helped create economies of scale and reduce operating costs. Wang [54] said that airlines can influence consumer purchase intention by enhancing the customer perception of brand equity and brand preference by joining a global airline alliance. However, product differentiation has become increasingly important because competition among airlines has led to the saturation of global airline alliances. According to Saeidi [55], an enhanced reputation and a competitive advantage are consequences of increased customer satisfaction after engaging in CSR. Thus, a clear CSR strategy is a good approach in constructing brand image [26]. 
Table 4. Key excerpts from the interview with the senior manager.

\begin{tabular}{|c|c|c|}
\hline Senior manager & Interview key excerpts & Criterion comparison \\
\hline \multirow{2}{*}{ Senior vice president 1} & $\begin{array}{l}\text { Airline customers and clients exhibit high regionality/locality, and CSR strategy must } \\
\text { capture local customers }\end{array}$ & Customer Relationship Management \\
\hline & $\begin{array}{l}\text { The freight route must be influenced by oil price and cost, and fleet management should be } \\
\text { considered along with CSR strategy }\end{array}$ & Fleet Management/Operational Eco-Efficiency \\
\hline \multirow{7}{*}{ Senior vice president 2} & CSR must be based on the health capital and pay attention to shareholder equity & \multirow{2}{*}{ Corporate Governance } \\
\hline & Cooperate governance transparency is the key factor of CSR & \\
\hline & Environmental protection should be combined with financial performance & Corporate Governance/Efficiency \\
\hline & Operational environmental activities should be based on reduced cost and increased revenue & Corporate Governance/Efficiency/Operational Eco-Efficiency \\
\hline & Brand value comes from customer perception of the airlines, and the basic factors include & Brand Management/ Product Responsibility (Safety)/ \\
\hline & safety, service quality, and intimacy & Customer Relationship Management \\
\hline & Abundant employee reward to encourage CSR activities in their daily work & Human Capital Development \\
\hline \multirow{5}{*}{ Senior vice president 3} & Bring up cross-function talents to allow CSR deepening in the company & Human Capital Development \\
\hline & The core value of the company must reflect on the CSR strategy & Corporate Governance \\
\hline & Trainings exhibit limitations, and CSR can help enhance employee loyalty and coherence & Talent Attraction and Retention \\
\hline & $\begin{array}{l}\text { In-flight products should exhibit the eco-design concept, such as low } \mathrm{CO}_{2} \text { emissions, } \\
\text { recycling, and reusing }\end{array}$ & Climate Change/Operational Eco-Efficiency \\
\hline & $\begin{array}{l}\text { Communication and propaganda are very important, as when the Boeing company delivery } \\
\text { flight gave clear information of design and manufacture with the sustainability concept of } \\
\text { the flight }\end{array}$ & $\begin{array}{l}\text { Stakeholder Engagement/Environment and Social Reporting } \\
\text { (Information Disclosure) }\end{array}$ \\
\hline \multirow{3}{*}{ Senior vice president 4} & $\begin{array}{l}\text { Improved public relation on the CSR approach for building up company image } \\
\text { and public trust }\end{array}$ & Customer Relationship Management/Brand Management \\
\hline & Concrete action, such as the plan for replacing a bus or vent by electric vehicle (EV) & Biofuel/Alternative energy \\
\hline & $\begin{array}{l}\text { Innovative environmental measure without cost, such as in reducing the temperature in the } \\
\text { landed aircraft to save the energy consumption of air conditioners; the crew can ask the } \\
\text { passengers to lower down the window shade before leaving the aircraft }\end{array}$ & Operational Eco-Efficiency \\
\hline
\end{tabular}


Table 4. Cont

\begin{tabular}{|c|c|c|}
\hline Senior manager & Interview key excerpts & Criterion comparison \\
\hline \multirow{3}{*}{ Senior vice president 5} & $\begin{array}{l}\text { Fuel efficiency is the main financial and environmental factor among airlines; we } \\
\text { can attempt finding the new flight along with prioritizing safety }\end{array}$ & Efficiency/Fleet Management/Product Responsibility (Safety) \\
\hline & $\begin{array}{l}\text { Finances, environment, and safety are the basis of airline CSR; thus, all } \\
\text { innovative practices must include these three key factors }\end{array}$ & Corporate Governance/Product Responsibility (Safety) \\
\hline & $\begin{array}{l}\text { Biofuel is the main topic of airlines in the near future; CSR strategy cannot } \\
\text { be ignored }\end{array}$ & Biofuel/Alternative energy \\
\hline \multirow{3}{*}{ Vice president 1} & $\begin{array}{l}\text { CSR should not only focus on charity, but must also construct strategy for all } \\
\text { dimensions to strengthen competitiveness }\end{array}$ & Corporate Citizenship and Philanthropy/Corporate Governance \\
\hline & $\begin{array}{l}\text { The employee is one of the key stakeholders; truly listening to employees will } \\
\text { increase their commitment }\end{array}$ & Labor Practice Indicators and Human Rights \\
\hline & $\begin{array}{l}\text { CSR strategy needs clear KPIs for managers to ensure that every function is on } \\
\text { the right track }\end{array}$ & Corporate Governance \\
\hline
\end{tabular}




\section{Conclusions and Future Research}

Although the airline industry plays an important role in the transportation and tourism sector, it also induces negative impacts, such as air pollutants, grave contributions to climate change, noise, and other economic and social issues. The pressure from the EU (European Commission Directorate-General for Climate Action [56]) to reduce the $\mathrm{CO}_{2}$ emissions is proof that the airline industry and IATA are committed to achieving carbon-neutral growth by 2020 . However, other issues such as economic and social concerns should also be addressed to enhance competitiveness. Therefore, airlines should start implementing comprehensive CSR strategies. However, some airlines, particularly those in Asia, are not establishing adequate CSR strategies.

This research constructed an evaluation model for airlines to examine the interrelationship among CSR issues and provide airlines with a clear vision for devising CSR strategies. For this purpose, an evaluation strategy that is comprehensive and suitable to the airline industry was built. By implementing the DEMATEL method with the expert insight from industrial, government and academic institutions, a clear influence map of total relationship was made. To obtain the viewpoint of an airline senior manager in regards to CSR strategy, five senior vice presidents and one vice president managing global airlines were consulted. The results of the DEMATEL method and senior managers' interview were compared.

\section{Limitations and Further Research}

This paper focused on identifying the CSR strategy of Asia-Pacific airlines; however, low-cost carriers (LCCs) were not considered. Nevertheless, the CSR strategies of both types of airlines are presumed similar, although the different operation models between global airlines and LCC may affect the key strategy factors.

For further research, the CSR strategies of rising LCCs in Asia-Pacific should be examined. As well, the results obtained in this research can be compared with the results of stakeholder engagement present in CSR reports of airlines to gain a more extensive discussion of CSR issues. Multiplicative methods applied in this field can also be studied.

\section{Author Contributions}

Dong-Shang Chang and Allen H. Hu designed the research; Sheng-Hung Chen and Chia-Wei Hsu performed the research; Dong-Shang Chang, Sheng-Hung Chen and Chia-Wei Hsu collected and analyzed data; Dong-Shang Chang, Sheng-Hung Chen, Chia-Wei Hsu and Allen H. Hu wrote the paper; finally, Chia-Wei Hsu revised the paper. All authors have read and approved the final manuscript.

\section{Conflicts of Interest}

The authors declare no conflict of interest. 


\section{Appendix}

Table A1. The matrix of total relation.

\begin{tabular}{|c|c|c|c|c|c|c|c|c|c|c|c|}
\hline & EC1 & EC2 & EC3 & EC4 & EC5 & EC6 & EC7 & EC8 & EC9 & EC10 & EN1 \\
\hline EC1 & 0.1118 & 0.1708 & 0.1333 & 0.1211 & 0.1420 & 0.1644 & 0.1399 & 0.1709 & 0.1458 & 0.1580 & 0.1068 \\
\hline EC2 & 0.1452 & 0.1012 & 0.1158 & 0.0910 & 0.1286 & 0.1456 & 0.1213 & 0.1469 & 0.1357 & 0.1470 & 0.1067 \\
\hline EC3 & 0.1227 & 0.1225 & 0.0554 & 0.0928 & 0.1021 & 0.1132 & 0.1061 & 0.1168 & 0.0963 & 0.1100 & 0.0613 \\
\hline EC4 & 0.1096 & 0.1152 & 0.1004 & 0.0416 & 0.0816 & 0.1083 & 0.1011 & 0.1032 & 0.0782 & 0.0916 & 0.0522 \\
\hline EC5 & 0.1020 & 0.1077 & 0.0709 & 0.0582 & 0.0588 & 0.1254 & 0.0882 & 0.1019 & 0.0774 & 0.0900 & 0.0587 \\
\hline EC6 & 0.1296 & 0.1333 & 0.0919 & 0.0827 & 0.1352 & 0.0903 & 0.1272 & 0.1390 & 0.1143 & 0.1138 & 0.0814 \\
\hline EC7 & 0.1069 & 0.1163 & 0.0800 & 0.0727 & 0.0934 & 0.1037 & 0.0616 & 0.1098 & 0.0848 & 0.1068 & 0.0686 \\
\hline EC8 & 0.1226 & 0.1232 & 0.0774 & 0.0658 & 0.1111 & 0.1257 & 0.1063 & 0.0838 & 0.1210 & 0.1283 & 0.0752 \\
\hline EC9 & 0.1103 & 0.1200 & 0.0687 & 0.0522 & 0.0967 & 0.1163 & 0.0926 & 0.1323 & 0.0677 & 0.1202 & 0.0849 \\
\hline EC10 & 0.1278 & 0.1373 & 0.0823 & 0.0704 & 0.1255 & 0.1400 & 0.1056 & 0.1408 & 0.1229 & 0.0789 & 0.0763 \\
\hline EN1 & 0.0939 & 0.1123 & 0.0540 & 0.0504 & 0.0742 & 0.0934 & 0.0865 & 0.1030 & 0.0974 & 0.0977 & 0.0479 \\
\hline EN2 & 0.0853 & 0.0889 & 0.0418 & 0.0392 & 0.0609 & 0.0848 & 0.0763 & 0.0886 & 0.0871 & 0.0868 & 0.0915 \\
\hline EN3 & 0.0673 & 0.0791 & 0.0378 & 0.0326 & 0.0710 & 0.0818 & 0.0677 & 0.0819 & 0.0720 & 0.0744 & 0.0619 \\
\hline EN4 & 0.1039 & 0.1139 & 0.0571 & 0.0473 & 0.0874 & 0.1042 & 0.0962 & 0.1018 & 0.0925 & 0.0959 & 0.0966 \\
\hline EN5 & 0.0861 & 0.0867 & 0.0488 & 0.0373 & 0.0677 & 0.0884 & 0.0886 & 0.0924 & 0.0816 & 0.0816 & 0.0850 \\
\hline SO1 & 0.1061 & 0.1155 & 0.0831 & 0.0752 & 0.1008 & 0.1120 & 0.0967 & 0.1123 & 0.1013 & 0.1056 & 0.0781 \\
\hline SO2 & 0.1055 & 0.1042 & 0.0829 & 0.0632 & 0.0831 & 0.1017 & 0.0834 & 0.1111 & 0.0834 & 0.0900 & 0.0528 \\
\hline SO3 & 0.1176 & 0.1080 & 0.0897 & 0.0664 & 0.1004 & 0.1141 & 0.0832 & 0.1240 & 0.1100 & 0.1110 & 0.0637 \\
\hline SO4 & 0.1181 & 0.1087 & 0.0781 & 0.0606 & 0.0982 & 0.1178 & 0.0865 & 0.1219 & 0.1137 & 0.1116 & 0.0614 \\
\hline SO5 & 0.0787 & 0.0716 & 0.0487 & 0.0433 & 0.0828 & 0.0989 & 0.0632 & 0.0719 & 0.0582 & 0.0608 & 0.0460 \\
\hline SO6 & 0.1104 & 0.1161 & 0.0779 & 0.0703 & 0.0907 & 0.1099 & 0.0892 & 0.1075 & 0.0913 & 0.0953 & 0.0683 \\
\hline SO7 & 0.1388 & 0.1517 & 0.0861 & 0.0740 & 0.1303 & 0.1483 & 0.1253 & 0.1432 & 0.1245 & 0.1327 & 0.0801 \\
\hline
\end{tabular}


Table A1. Cont.

\begin{tabular}{|c|c|c|c|c|c|c|c|c|c|c|c|}
\hline & EN2 & EN3 & EN4 & EN5 & SO1 & $\mathrm{SO} 2$ & SO3 & SO4 & SO5 & SO6 & SO7 \\
\hline EC1 & 0.0957 & 0.0860 & 0.1272 & 0.1171 & 0.1391 & 0.1208 & 0.1265 & 0.1319 & 0.1165 & 0.1232 & 0.1445 \\
\hline EC2 & 0.0824 & 0.0845 & 0.1169 & 0.1040 & 0.1065 & 0.0981 & 0.0999 & 0.0989 & 0.0769 & 0.1055 & 0.1354 \\
\hline EC3 & 0.0556 & 0.0500 & 0.0694 & 0.0652 & 0.0934 & 0.0844 & 0.0912 & 0.1005 & 0.0670 & 0.0847 & 0.0980 \\
\hline EC4 & 0.0471 & 0.0449 & 0.0592 & 0.0577 & 0.0829 & 0.0657 & 0.0688 & 0.0718 & 0.0545 & 0.0773 & 0.0844 \\
\hline EC5 & 0.0537 & 0.0515 & 0.0684 & 0.0673 & 0.0791 & 0.0579 & 0.0642 & 0.0732 & 0.0666 & 0.0738 & 0.0829 \\
\hline EC6 & 0.0693 & 0.0692 & 0.0907 & 0.0866 & 0.1018 & 0.0836 & 0.0910 & 0.1010 & 0.0920 & 0.1045 & 0.1153 \\
\hline EC7 & 0.0606 & 0.0519 & 0.0846 & 0.0866 & 0.0860 & 0.0631 & 0.0635 & 0.0638 & 0.0659 & 0.0740 & 0.1018 \\
\hline EC8 & 0.0723 & 0.0606 & 0.0953 & 0.0915 & 0.0841 & 0.0760 & 0.0861 & 0.0957 & 0.0694 & 0.0932 & 0.0977 \\
\hline EC9 & 0.0824 & 0.0854 & 0.0930 & 0.0923 & 0.0737 & 0.0621 & 0.0717 & 0.0783 & 0.0567 & 0.0740 & 0.0901 \\
\hline EC10 & 0.0703 & 0.0644 & 0.0878 & 0.0865 & 0.0856 & 0.0742 & 0.0843 & 0.0884 & 0.0675 & 0.0828 & 0.1089 \\
\hline EN1 & 0.0917 & 0.0561 & 0.1062 & 0.1059 & 0.0837 & 0.0503 & 0.0505 & 0.0564 & 0.0704 & 0.0777 & 0.0836 \\
\hline EN2 & 0.0384 & 0.0606 & 0.0945 & 0.1032 & 0.0744 & 0.0419 & 0.0447 & 0.0503 & 0.0626 & 0.0627 & 0.0707 \\
\hline EN3 & 0.0551 & 0.0313 & 0.0852 & 0.0850 & 0.0661 & 0.0413 & 0.0409 & 0.0493 & 0.0554 & 0.0610 & 0.0682 \\
\hline EN4 & 0.0882 & 0.0943 & 0.0585 & 0.1099 & 0.0966 & 0.0566 & 0.0598 & 0.0660 & 0.0772 & 0.0875 & 0.0846 \\
\hline EN5 & 0.0747 & 0.0720 & 0.0886 & 0.0484 & 0.0749 & 0.0460 & 0.0546 & 0.0545 & 0.0572 & 0.0693 & 0.0684 \\
\hline SO1 & 0.0667 & 0.0702 & 0.0919 & 0.0881 & 0.0591 & 0.0756 & 0.0763 & 0.0771 & 0.0788 & 0.0872 & 0.0997 \\
\hline $\mathrm{SO2}$ & 0.0447 & 0.0426 & 0.0662 & 0.0622 & 0.0841 & 0.0458 & 0.0955 & 0.1075 & 0.0775 & 0.0821 & 0.0843 \\
\hline SO3 & 0.0494 & 0.0470 & 0.0775 & 0.0823 & 0.0828 & 0.0922 & 0.0536 & 0.1089 & 0.0723 & 0.0837 & 0.0807 \\
\hline SO4 & 0.0528 & 0.0506 & 0.0782 & 0.0802 & 0.0862 & 0.0955 & 0.1086 & 0.0576 & 0.0758 & 0.0871 & 0.0870 \\
\hline SO5 & 0.0420 & 0.0436 & 0.0544 & 0.0538 & 0.0683 & 0.0522 & 0.0608 & 0.0663 & 0.0334 & 0.0696 & 0.0552 \\
\hline SO6 & 0.0599 & 0.0576 & 0.0758 & 0.0747 & 0.0864 & 0.0739 & 0.0804 & 0.0837 & 0.0730 & 0.0529 & 0.0810 \\
\hline SO7 & 0.0766 & 0.0676 & 0.0922 & 0.0936 & 0.1018 & 0.0744 & 0.0787 & 0.0885 & 0.0738 & 0.0867 & 0.0739 \\
\hline
\end{tabular}




\section{References}

1. Chang, Y.C.; Yu, M.M.; Chen, P.C. Evaluating the performance of chinese airports. J. Air Transp. Manag. 2013, 31, 19-21.

2. Wang, Q.; Wu, C.; Sun, Y. Evaluating corporate social responsibility of airlines using entropy weight and grey relation analysis. J. Air Transp. Manag. 2015, 42, 55-62.

3. Lee, S.; Park, S.Y. Financial impacts of socially responsible activities on airline companies. J. Hosp. Tour. Res. 2010, 34, 185-203.

4. Chen, F.Y.; Chang, Y.H.; Lin, Y.H. Customer perceptions of airline social responsibility and its effect on loyalty. J. Air Transp. Manag. 2012, 20, 49-51.

5. Cowper-Smith, A.; de Grosbois, D. The adoption of corporate social responsibility practices in the airline industry. J. Sustain. Tour. 2011, 19, 59-77.

6. Searcy, C.; Elkhawas, D. Corporate sustainability ratings: An investigation into how corporations use the dow jones sustainability index. J. Clean. Prod. 2012, 35, 79-92.

7. RobecoSam. The sustainability yearbook 2015. Available online: http://yearbook.robecosam.com/ files/rs_data/pdf/RobecoSAM_Sustainability_Yearbook_2015.pdf (accessed on 15 June 2015).

8. Global Reporting Initiative. Sustainability reporting guidelines g 3.1. Available online: https://www.globalreporting.org/resourcelibrary/G3.1-Guidelines-Incl-Technical-Protocol.pdf (accessed on 15 June 2015).

9. Global Reporting Initiative. Sustainability reporting guidelines g4. Available online: https://www.globalreporting.org/reporting/g4 (accessed on 15 June 2015).

10. International Air Transport Association (IATA). Available online: http://www.iata.org/about/ Pages/index.aspx (accessed on 15 June 2015).

11. International Civil Aviation Organization (ICAO). Available online: http://www.icao.int/Pages/ default.aspx (accessed on 15 June 2015).

12. Govindan, K.; Kannan, D.; Kannan, D. Evaluating the drivers of corporate social responsibility in the mining industry with multi-criteria approach: A multi-stakeholder perspective. J. Clean. Prod. 2014, 84, 214-232.

13. Hsu, C.C.; Liou, J.J.H. An outsourcing provider decision model for the airline industry. J. Air Transp. Manag. 2013, 28, 40-46.

14. Hsu, C.W.; Lee, W.H.; Chao, W.C. Materiality analysis model in sustainability reporting: A case study at lite-on technology corporation. J. Clean Prod. 2013, 57, 142-151.

15. Lin, R.J. Using fuzzy dematel to evaluate the green supply chain management practices. J. Clean Prod. 2013, 40, 32-39.

16. Ou Yang, Y.P.; Shieh, H.M.; Tzeng, G.H. A vikor technique based on dematel and anp for information security risk control assessment. Inf. Sci. 2013, 232, 482-500.

17. Liou, J.J.H. Developing an integrated model for the selection of strategic alliance partners in the airline industry. Knowl.-Based Syst. 2012, 28, 59-67.

18. Tsai, W.H.; Hsu, J.L. Corporate social responsibility programs choice and costs assessment in the airline industry-A hybrid model. J. Air Transp. Manag. 2008, 14, 188-196.

19. Liou, J.J.H.; Yen, L.; Tzeng, G.H. Building an effective safety management system for airlines. J. Air Transp. Manag. 2008, 14, 20-26. 
20. Coles, T.; Fenclova, E.; Dinan, C. Tourism and corporate social responsibility: A critical review and research agenda. Tour. Manag. Perspect. 2013, 6, 122-141.

21. Amini, M.; Bienstock, C.C. Corporate sustainability: An integrative definition and framework to evaluate corporate practice and guide academic research. J. Clean. Prod. 2014, 76, 12-19.

22. Elkington, J. Cannibals with Forks: Triple Bottom Line of 21st Century Business; Capstone Publishing Ltd.: Mankato, MN, USA, 1998.

23. The World Business Council on Sustainable Development (WBCSD). Corporate Social Responsibility: Meeting Changing Expectations; WBCSD: Geneva, Switzerland, 1999.

24. Zhao, Z.Y.; Zhao, X.J.; Davidson, K.; Zuo, J. A corporate social responsibility indicator system for construction enterprises. J. Clean Prod. 2012, 29-30, 277-289.

25. Lynes, J.K.; Andrachuk, M. Motivations for corporate social and environmental responsibility: A case study of scandinavian airlines. J. Int. Manag. 2008, 14, 377-390.

26. Lee, S.; Seo, K.; Sharma, A. Corporate social responsibility and firm performance in the airline industry: The moderating role of oil prices. Tour. Manag. 2013, 38, 20-30.

27. Fenclova, E.; Coles, T. Charitable partnerships among travel and tourism businesses: Perspectives from low-fares airlines. Int. J. Tour. Res. 2011, 13, 337-354.

28. Mak, B.L.M.; Chan, W.W. A study of environmental reporting: International japanese airlines. Asia Pac. J. Tour. Res. 2007, 12, 303-312.

29. Mak, B.L.M.; Chan, W.W.H.; Wong, K.; Zheng, C. Comparative studies of standalone environmental reports-European and asian airlines. Transp. Res. Part D Transp. Environ. 2007, $12,45-52$.

30. Chang, D.S.; Kuo, L.C.R. The effects of sustainable development on firms' financial performance? An empirical approach. Sustain. Dev. 2008, 16, 365-380.

31. International Civil Aviation Organization (ICAO). 2013 environmental report. Available online: http://www.icao.int/environmental-protection/Pages/EnvReport13.aspx (accessed on 15 June 2015).

32. Carbon Disclosure Project (CDP). Climate change program. Available online: https://www.cdp.net/ en-US/Programmes/Pages/CDP-Investors.aspx (accessed on 15 June 2015).

33. United Nations. Global compact. Available online: https://www.unglobalcompact.org/ (accessed on 15 June 2015).

34. International Labour Organization. Available online: https: www.ilo.org/ (accessed on 15 June 2015).

35. Wu, W.W.; Lee, Y.T. Developing global managers' competencies using the fuzzy dematel method. Expert Syst. Appl. 2007, 32, 499-507.

36. Chiu, Y.J.; Chen, H.C.; Tzeng, G.H.; Shyu, J.Z. Marketing strategy based on customer behaviour for the LCD-TV. Int. J. Manag. Decis. Mak. 2006, 7, 143-165.

37. Hori, S.; Shimizu, Y. Designing methods of human interface for supervisory control systems. Control Eng. Pract. 1999, 7, 1413-1419.

38. Hsu, C.W.; Kuo, T.C.; Chen, S.H.; Hu, A.H. Using dematel to develop a carbon management model of supplier selection in green supply chain management. J. Clean Prod. 2013, 56, 164-172.

39. Tsai, W.H.; Chou, W.C. Selecting management systems for sustainable development in smes: A novel hybrid model based on dematel, anp, and zogp. Expert Syst. Appl. 2009, 36, 1444-1458.

40. Tzeng, G.H.; Chiang, C.H.; Li, C.W. Evaluating intertwined effects in e-learning programs: A novel hybrid mcdm model based on factor analysis and dematel. Expert Syst. Appl. 2007, 32, 1028-1044. 
41. Teng, J.Y. Project Evaluation: Methods and Applications; National Taiwan Ocean University: Keelung, Taiwan, 2002.

42. Saaty, T.L.; Vargas, L.G. Decision Making in Economic, Political, Social, and Technological Environments with the Analytic Hierarchy Process; RWS Publications: Pittsburgh, PA, USA. 1994.

43. Lee, C.C.; Chiang, C.; Chen, C.T. An evaluation model of e-service quality by applying hierarchical fuzzy TOPSIS method. Int. J. Electron. Bus. Manag. 2012, 10, 38-49.

44. Tzeng, G.-H.; Huang, C.-Y. Combined dematel technique with hybrid mcdm methods for creating the aspired intelligent global manufacturing and logistics systems. Ann. Oper. Res. 2012, 197, 159-190.

45. Ammann, M.; Oesch, D.; Schmid, M.M. Corporate governance and firm value: International evidence. J. Empir. Financ. 2011, 18, 36-55.

46. Olson, D.L.; Wu, D. Innovative csr: From risk management to value creation. J. Clean. Prod. 2010, $18,1767-1768$.

47. Air France KLM. 2013 CSR report. Avaliable online: http://www.airfranceklm.com/sites/ default/files/publications/2013_radd-en.pdf (accessed on 15 June 2015).

48. Lufthansa group. 2013 sustainability report. Avaliable online: http://www.lufthansagroup.com/ fileadmin/downloads/en/responsibility/balance-2014-epaper/ (accessed on 15 June 2015).

49. Qantas. 2013 Integrated ESG analysis. Avaliable online: http://www.qantas.com.au/infodetail/ about/investors/qantas-sustainability-review-2013.pdf (accessed on 15 June 2015).

50. ANA Holdings. Annual report 2014. Avaliable online: http://www.anahd.co.jp/en/investors/ data/pdf/annual/14/14_00.pdf (accessed on 15 June 2015).

51. Cathay Pacific. Sustainable development report 2013. Avaliable online: http://downloads.cathaypacific.com/cx/aboutus/sd/2013/index.html (accessed on 15 June 2015).

52. European Commission. European advanced biofuel flight path. Avaliable online: http://ec.europa.eu/energy/en/topics/biofuels/biofuels-aviation (accessed on 15 June 2015).

53. International Civil Aviation Organization (ICAO). Balanced approach to aircraft noise management. Avaliable online: http://www.icao.int/environmental-protection/Pages/noise.aspx (accessed on 15 June 2015).

54. Wang, S.W. Do global airline alliances influence the passenger's purchase decision? J. Air Transp. Manag. 2014, 37, 53-59.

55. Saeidi, S.P.; Sofian, S.; Saeidi, P.; Saeidi, S.P.; Saaeidi, S.A. How does corporate social responsibility contribute to firm financial performance? The mediating role of competitive advantage, reputation, and customer satisfaction. J. Bus. Research 2015, 68, 341-350.

56. European Commission. Directorate-general for climate action. Avaliable online: http://ec.europa.eu/clima/policies/transport/aviation/documentation_en.htm (accessed on 15 June 2015).

(C) 2015 by the authors; licensee MDPI, Basel, Switzerland. This article is an open access article distributed under the terms and conditions of the Creative Commons Attribution license (http://creativecommons.org/licenses/by/4.0/). 